\title{
A Rare Cause of Female Gender Dysphoria: Report of Three Cases with Low Percentage of Turner Mosaicism
}

\author{
Kadın Cinsiyet Disforisinin Nadir Bir Nedeni: Düşük Yüzdeli Turner Mozaisizmli Üç Olgu Raporu
}

\author{
Seda ERISŞEN KARACA ${ }^{\mathbf{1}}$ \\ (1) 0000-0002-8899-8412 \\ Recep ERÖZ $Z^{2}$ \\ (D) 0000-0003-0840-2613 \\ İlknur ARSLANOĞLU ${ }^{1}$ \\ (D) 0000-0002-4975-9718
}

${ }^{1}$ Düzce University Medical Faculty, Department of Pediatrics, Düzce, Turkey

${ }^{2}$ Düzce University Medical Faculty, Department of Medical Genetics, Düzce, Turkey

\section{Corresponding Author Sorumlu Yazar \\ Seda ERIŞEN KARACA \\ drsedaerisen@hotmail.com}

Received / Geliş Tarihi : 15.08.2020 Accepted / Kabul Tarihi : 12.12.2020 Available Online /

Çevrimiçi Yayın Tarihi : 25.12.2020

\begin{abstract}
Gender dysphoria is a condition caused by a mismatch between the gender assigned at birth and gender identity. Gender development disorders include situations where congenital chromosomal, gonadal, or anatomically gender-related physical features are atypical. In the studies conducted mostly by karyotype analysis, it is reported that the rate of chromosomal abnormality is very low in people with gender dysphoria. In Turner mosaicism, gender dysphoria is not a common finding. In this case series, we examined the phenotype and genotype characteristics of the three cases identified as Turner mosaicism, who applied with gender dysphoria. The patients' complaints were feeling like a male, negative thoughts about being a female, being uncomfortable with feminine body image, wanting to have a male body. None of our 3 cases had Turner stigmata however their chromosomal or FISH analyses showed that one of them was 45,X/46 XX/47, XXX and two of them were $45 \mathrm{X} / 46 \mathrm{XX}$ karyotype.

Keywords: Turner's syndrome; gender dysphoria; karyotype; FISH.
\end{abstract}

ÖZ

Cinsiyet disforisi, doğumda belirlenen cinsiyet ile cinsiyet kimliği arasındaki uyumsuzluğun neden olduğu bir durumdur. Cinsiyet gelişim bozuklukları, konjenital kromozomal, gonadal veya anatomik olarak cinsiyetle ilişkili fiziksel özelliklerin atipik olduğu durumları içerir. Çoğunlukla karyotip analizi ile yapılan çalışmalarda cinsiyet disforisi olan kişilerde kromozomal anormallik oranının çok düşük olduğu bildirilmektedir. Turner mozaisizminde cinsiyet disforisi yaygın bir bulgu değildir. Bu olgu serisinde, cinsiyet disforisi ile başvuran Turner mozaisizmi olarak tanımlanan üç olgunun fenotip ve genotip özelliklerini inceledik. Hastaların şikayetleri erkek gibi hissetmek, kadın olmakla ilgili olumsuz düşünceler, kadın beden imajından rahatsız olmak, erkek bedene sahip olmak istemek şeklindeydi. 3 olgumuzun hiçbirinde Turner stigmatası yoktu ancak kromozomal veya FISH analizleri, birinde 45,X/46 XX/47,XXX ve ikisinde 45 X/46 XX olarak tespit edildi.

Anahtar kelimeler: Turner sendromu; cinsiyet disforisi; karyotip; FISH.

\section{INTRODUCTION}

Gender dysphoria (GD) can be described as a conflict between a person's assigned gender and gender identity (1). People with GD may be very uncomfortable with their assigned gender, sometimes the reason is their body (particularly developments during puberty) and sometimes it is the expected roles of their assigned gender (2). Contrarily, disorders of sexual development (DSD) refer to a range of congenital conditions including the chromosomal anomalies, gonads, and/or genitalia (3). It is reported that $5 \%$ of people diagnosed with gender development disorders have GD. Although GD and DSD are distinct entities, they can coexist. Thus, when evaluating an individual with suspected GD, it is crucial to know whether he/she also has a DSD (2). 
To make a diagnose of "Gender Identity Disorder", according to DSM IV-TR, and "Transsexualism" (F64.0) according to ICD-10, GD should not be related with an abnormality of gender chromosomes, or another disorder of sex development. DSM-5, removed accompanying DSD in GD diagnosis category from exclusion criterion for the diagnosis, and suggested that if they are present, should be indicated $(1,4)$. However, some DSD types such as complete androgen insensitivity syndrome (CAIS), XY gonadal dysgenesis and Klinefelter syndrome may remain undiagnosed since clinical symptoms do not manifest until adolescence. In these cases, the diagnosis of GD may therefore forego doubt of a DSD, particularly in persons who's gender identity concerns appear in early period of life $(2,5)$.

Turner syndrome (TS), one of the most frequent chromosomal disorder in female live births, is characterized by partial or complete lack of one $\mathrm{X}$ chromosome and its estimated incidence is $1 / 2500$. Even though classic TS karyotype is $45, \mathrm{X}, 30-40 \%$ of the remaining have a mosaic type with a second cell line (45,X/46,XX, 45,X/47,XYY, 45,X/46,XY, 45,X/47,XXX and $46, X, \operatorname{del} X q)(6,7)$.

Some patients may be diagnosed at birth because of dysmorphic findings but the diagnosis may be delayed until childhood, adolescence or later $(6,7)$. Clinical features of TS are short stature, characteristic stigmata, primary amenorrhea and infertility. The characteristic phenotypic findings of the disease are, low-set ears, low nuchal hair line, cubitus valgus, high palate, small mandibula, nail hypoplasia, short $4^{\text {th }}$ metacarpal bone, swelling of the hands and feet in the neonatal period, discrete nipples and wide thoracic cage. Also system anomalies including cardiac and renal anomalies, gastrointestinal and dermatological problems, neoplasms, hypothyroidism, vision disorders, hearing loss (6) neurodevelopmental and behavioral problems are also general findings in patients with TS (8).

In the literature, very few mosaic TS in chromosome analysis of broad GD series have been reported. In this case series, we examined the phenotype and genotype characteristics of the three cases identified as Turner mosaicism, who applied with GD.

\section{CASE REPORT}

Routine hemogram, biochemistry, thyroid functions as well as antibodies and hormone profile were normal in all cases. Pelvic ultrasonography (USG) showed multiple anechoic follicles in bilateral ovaries in all cases.

CASE 1: 15 years and 9 months old girl patient applied with complaints of liking people of her own sex and gender dissatisfaction which are present for 2-3 years. During childhood period, the patient behaved in accordance with her gender, played with her girlfriends and girls' toys. During puberty, the patient started to like girls more and more. Desire to have a male body arose. She attempted suicide by taking drugs at the age of 15 . The patient had spontaneous pubarche, thelarche, and menarche at 12 years with irregular menses. She had a gynecoid waist/pelvis ratio and big breasts but mild hirsutism. She had no Turner stigmata. Results of an echocardiogram and renal USG were normal. MTHFR C677T homozygous mutation and PAI-I:4G-5G mutation were detected in the thrombophilia panel. Other physical and laboratory values are given at Table 1. Karyotype analysis was performed from the peripheral blood and low percentage of a mosaicism was detected (46, XX[63] / 45, X[2]) (Figure $1 \mathrm{a}$ and $1 \mathrm{~b})$. FISH $(\mathrm{X}, \mathrm{Y})$ analysis was performed using CEP X (DXZ1), CEP Y (DYZ3) (Cytocell) probe and revealed nuc ish(CEP X x 1)[8]/(CEP X x 2)[490]/(CEP X x 3)[2] chromosomal composition.

CASE 2: 12 years and 4 months old girl admitted with negative thoughts about being a female, and being uncomfortable with feminine body shape and feeling like a male with increasing qualifications characteristics for the last 6 months. She had spontaneous pubarche, thelarche and menarche at 11 years with irregular menses. Karyotype analysis was performed from the peripheral blood and 46,XX karyotype was detected (Figure 1c). Because of the case's masculine self-perception FISH $(\mathrm{X}, \mathrm{Y})$ analysis was performed using CEP X (DXZ1), CEP Y (DYZ3) (Cytocell) probe and nuc ish(CEP X x 1)[4]/ (CEP X x 2)[146] chromosomal composition was detected. CASE 3: 17 years old girl applied with complaints that started in adolescence such as being sexually interested in girls, feeling uncomfortable with breasts and menstruation, and wanting to have a male body. She had spontaneous pubarche, thelarche and menarche at 13 years with regular menses. She had no Turner stigmata and hirsutism.

Karyotype analysis was performed from the peripheral blood and 46,XX karyotype was detected (Figure 1d). Due to her masculine feelings, FISH $(\mathrm{X}, \mathrm{Y})$ analysis was performed using CEP X (DXZ1), CEP Y (DYZ3) (Cytocell) probe and nuc ish(CEP X x 1)[6]/(CEP X X 2)[294] chromosomal composition was detected in interphase nuclei.
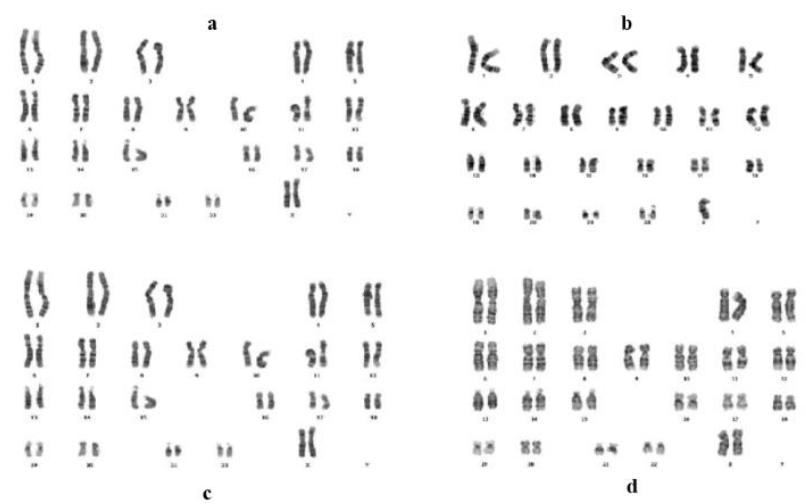

Figure 1. Karyotype analysis of cases using conventional $\mathrm{G}$ banding techniques, $\mathrm{a}-\mathrm{b})$ Case 1, c) Case 2, d) Case 3

\section{DISCUSSION}

Considering the studies conducted with GD and transgender patients using conventional $G$ banding techniques, an overall rate of chromosomal abnormalities in $11 / 481$ trans females $(2.3 \%)$ was reported $(5,9-12)$. (One of these, about mosaic TS with $45, \mathrm{X}[10] / 47, \mathrm{XXX}[6] / 46, \mathrm{XX}[98]$ karyotype and without pubertal or hormonal disturbance (5).) Bağcaz et al. (13) performed $\mathrm{G}$ banding from 154 female-to-male transsexualism cases and TS was not represented in their sample. Pang et al. (14) have performed molecular 
Table 1. Physical and laboratory values of cases

\begin{tabular}{lccc}
\hline & Case 1 & Case 2 & Case 3 \\
\hline Age & 15 year 9 month & 12 year 4 month & 17 year 3 month \\
Height (SDS) & 1.8 & 0.13 & 1.6 \\
Weight (SDS) & 2.78 & 0.47 & 1.08 \\
BMI (SDS) & 2.26 & 0.57 & 0.23 \\
Tanner stage & 5 & 4 & 5 \\
Menarche start & 12 & 11 & 13 \\
FSH (mIU/mL) & 6.65 & 4.86 & 7.58 \\
LH (mIU/mL) & 10.16 & 6.34 & 5.18 \\
E2 (pg/mL) & 55.5 & 84 & 58 \\
Testosterone & 0.64 & 0.32 & 0.01 \\
Karyotype & 46 XX & $45, X(4) / 46$ XX(146) & 46 XX \\
FISH & absent & absent & $45 X O(6) / 46 X X(294)$ \\
Turner stigmata & mild & absent & absent \\
Hirsutism & yes & yes & absent \\
Irregular menses & MTHFR C677T homozygous & Bicuspid Aorta & no \\
Additional findings & mutation and PAI-I:4G-5G mutation & &
\end{tabular}

karyotyping from 128 Australians with GD and reported in a normal karyotype $117 / 128(92.1 \%)$ of the patients, TS was not represented in their sample. So they suggested that molecular karyotyping has minimal clinical benefit in the routine management of GD. In another study, performed between 2000 and 2016 years in the Barcelona and Málaga (Spain); the G-banding techniques and high-resolution microarrays were performed from 444 male-to-females and 273 female-to-males and significantly higher Klinefelter syndrome frequency $(1.13 \%)$ was detected but TS was not represented (15).

In another study, 80 adult women with TS were evaluated for the psychosocial and sexual function and it was concluded that most affected women report being heterosexual despite they are less likely than their peers to have sexual relationships and to be at an older age (16). Regarding these studies, Turner mosaicism has been reported to a neglectable extent in the wide range of sex dysphoria. Due to the absence of karyotyping and FISH analyses in most studies, patients who are low mosaic Turner's are missed. Although karyotype analysis were normal in our $2^{\text {nd }}$ and $3^{\text {rd }}$ patients, low mosaicism was detected in FISH analyses of these cases. Our case had a low percentage of a cases mosaicism on peripheral blood, they had clinical findings related with this karyotype. May this situation be explained by the ratio of mosaicism being different in other tissues? To obtain more certain knowledge additional studies in large series should be performed. The most interesting observation of us is that despite this sparsity of relationship between GD and TS, the cases reported in these series are the 3 GD cases who applied consequently during the last year to our pediatric endocrinology outpatient clinic and our 13 years experience about GD comprises of less than 10 cases! Many of the mosaic patients may not have Turner stigmata and their heights may be normal. Patients may have normal puberty, menarche timing and even normal fertility $(6,7)$. There are some correlations between karyotype and phenotype. TS patients with $45, \mathrm{X} / 46, \mathrm{XX}$ or $45, \mathrm{X} / 47, \mathrm{XXX}$ mosaic karyotype are presumably to have spontaneous menarche and fertility. TS patients with 45,X/46,XX karyotype are marginally taller than other patients with TS (17). Our patient's heights were all (although one of them slightly) above mean. All 3 patients had normal menarche time, and our patients 1 and 2 had menstrual irregularities. Polycystic ovary (PCO) image was available in pelvic USG. Few cases have been reported with mosaicism and polycystic ovary syndrome (PCOS) comorbidity (18). Approximately $22-33 \%$ of the general population show PCOs on pelvic ultrasound. Classic PCOS, on the other hand, is found in approximately $5-10 \%$ of the general population with its clinical and biochemical properties (19). In a study of patients with GD including 69 femaleto-male transsexualism cases, 40 (58\%) were found to have PCOS. Female-to-male transsexual patients have a high prevalence of PCOS and hyperandrogenaemia (20). In our patients, testosterone levels were slightly high. In another study, a significantly higher prevalence of PCO and PCOS in lesbians compared with heterosexual women was reported. Lesbian women with either PCO or PCOS had more prominent hyperandrogenism than heterosexual women with either PCO or PCOS (21). It was reported that women with PCOS have psychological gender identification problems. Severity and duration of PCOS can negatively affect the self-image of cases, cause a disturbed recognition with the female-gender scheme and related with it, social roles (22).

It was reported that due to the high frequency of chromosomal mosaicism in TS, this syndrome is an interesting model for evaluation the relation between nondisjunction and MTHFR gene polymorphisms. Santos et al. (23) reported increasing frequency of the MTHFR $677 \mathrm{C}>\mathrm{T}$ homozygote alteration in patients with TS. According to our result, the case with 45,X/46,XX/47,XXX genotype had homozygote both MTHFR $677 \mathrm{C}>\mathrm{T}$ and PAI variation. Importance of pericentromeric DNA methylation for chromosomal stabilization and segregation. They announced that the 
MTHFR 677C > T homozygote alteration may be a contributing risk factor to somatic chromosomal nondisjunction (23). Also in our case 1, homozygous MTHFRC677T and 4G/5G variation in PAI were detected. Does the mosaic Turner karyotyping might have caused the homozygous MTHFRC677T variation that may be contributing risk factor to somatic chromosomal nondisjunction. To obtain more certain knowledge, additional studies including large series should be performed.

We offer interesting cases in this regard and we have mentioned in detail the patient's clinical profile. Even if these patients have normal phenotype, low percentage of Turner mosaicism should be considered. Early karyotype and FISH analysis in children with such cases can provide early detection of the mosaicism, thus more effective treatment strategy for the management of the disease can be performed. In clinically suspected cases, karyotype analysis should be confirmed with the FISH method even if it is normal.

Informed Consent: Written informed consent was obtained from the patient's parents for publication of this case report and the accompanying images.

Conflict of Interest: None declared by the authors.

Financial Disclosure: None declared by the authors.

Acknowledgements: None declared by the authors.

\section{REFERENCES}

1. American Psychiatric Association (APA). Diagnostic and statistical manual of mental disorders (DSM-5). 5th ed. Washington DC: APA Publishing; 2013.

2. Fisher AD, Ristori J, Fanni E, Castellini G, Forti G, Maggi M. Gender identity, gender assignment and reassignment in individuals with disorders of sex development: A major of dilemma. J Endocrinol Invest. 2016;39(11):1207-24.

3. Hughes IA, Houk C, Ahmed SF, Lee PA. Consensus statement on management of intersex disorders. Arch Dis Child. 2006;91(7):554-63.

4. The World Professional Association for Transgender Health (WPATH). Standards of care for the health of transsexual, tansgender, and gender nonconforming people. 7th ed. WPATH; 2011.

5. Auer MK, Fuss J, Stalla GK, Athanasoulia AP. Twenty years of endocrinologic treatment in transsexualism: analyzing the role of chromosomal analysis and hormonal profiling in the diagnostic work-up. Fertil Steril. 2013;100(4):1103-10.

6. Hook EB, Warburton D. The distribution of chromosomal genotypes associated with Turner's syndrome: livebirth prevalence rates and evidence for diminished fetal mortality and severity in genotypes associated with structural $\mathrm{X}$ abnormalities or mosaicism. Hum Genet 1983;64(1):24-7.

7. Gürsoy S, Erçal D. Turner syndrome and its variants. J Pediatr Res. 2017;4(4):171-5.

8. Yalçın SS, Çelen Yoldaş T, Ütine GE. Case management guidelines on neurodevelopmental and psychosocial problems of Turner syndrome. Turkish $\mathbf{J}$ Pediatr Dis. 2018;12(1):62-7.

9. Onur Cura D, Çankaya T, Ülgenalp A. The role of genetic factors in gender dysphoria. Hitit Med J 2020;2(2):49-55.

10. Wylie KR, Steward D. A consecutive series of 52 transsexual people presenting for assessment and chromosomal analysis at a gender identity clinic. Int $\mathbf{J}$ Transgend. 2008;10(3-4):147-8.

11. Vujovic S, Popovic S, Sbutega-Milosevic G, Djordjevic M, Gooren L. Transsexualism in Serbia: a twenty-year follow-up study. J Sex Med. 2009;6(4):1018-23.

12. Hengstschläger $M$, van Trotsenburg $M$, Repa $C$, Marton E, Huber JC, Bernaschek G. Sex chromosome aberrations and transsexualism. Fertil Steril. 2003;79(3):639-40.

13. Bağcaz A, Boduroğlu OK, Başar K. Chromosome analysis in the assessment for gender affirmation process: a retrospective study. Turk Psikiyatri Derg. 2019;30(3):157-62.

14. Pang KC, Feldman D, Oertel R, Telfer M. Molecular karyotyping in children and adolescents with gender dysphoria. Transgend Health. 2018;3(1):147-53.

15. Fernández R, Guillamón A, Gómez-Gil E, Esteva I, Almaraz MC, Cortés-Cortés J, et al. Analyses of karyotype by G-banding and high-resolution microarrays in a gender dysphoria population. Genes Genomics. 2018;40(5):465-73.

16. Pavlidis K, McCauley E, Sybert VP. Psychosocial and sexual functioning in women with Turner syndrome. Clin Genet. 1995;47(2):85-9.

17. Sybert VP. Phenotypic effects of a mosaicism for a $47, \mathrm{XXX}$ cell line in Turner syndrome. J Med Genet. 2002;39(3):217-20.

18. Givens JR, Wilroy RS, Summitt RL, Andersen RN, Wiser WL, Fish SA. Features of Turner's syndrome in women with polycystic ovaries. Obstet Gynecol. 1975;45(6):619-24.

19. Balen AH, Laven JS, Tan SL, Dewailly D. The ultrasound assessment of the polycystic ovary: international consensus definition. Hum Reprod Update. 2003;9(6):505-14.

20. Baba T, Endo T, Honnma H, Kitajima Y, Hayashi T, Ikeda $\mathrm{H}$, et al. Association between polycystic ovary syndrome and female-to-male transsexuality. Hum Reprod. 2007:22(4);1011-6.

21. Agrawal R, Sharma S, Bekir J, Conway G, Bailey J, Balen AH, et al. Prevalence of polycystic ovaries and polycystic ovary syndrome in lesbian women compared with heterosexual women. Fertil Steril. 2004;82(5):1352-7.

22. Kowalczyk R, Skrzypulec V, Lew-Starowicz Z, Nowosielski K, Grabski B, Merk W. Psychological gender of patients with polycystic ovary syndrome. Acta Obstet Gynecol Scand. 2012;91(6):710-4.

23. Santos K, Lemos-Marini S, Baptista M, Bonadia L, Júnior WP, Bertuzzo CP. Frequency of $677 \mathrm{C}>\mathrm{T}$ and $1298 \mathrm{~A}>\mathrm{C}$ polymorphisms in the 5,10methylenetetrahydrofolate reductase (MTHFR) gene in Turner syndrome individuals. Genet Mol Biol. 2006;29(1):41-4. 